\title{
FORMULASI SEDIAAN MOUTHWASH DARI SARI BUAH SIRIH (Piper betle L.) VARIETAS SIRIBOAH
}

\author{
Ririn, Amran Ilyas Tandjung, Sarif Wagola \\ Fakultas Farmasi Universitas Muslim Indonesia \\ Email :ririnrays@gmail.com
}

\begin{abstract}
Piper betle fruit empirically is believed to maintain oral health, but unfortunately the use of piper betle fruit not to be proven scientifically, therefore one of the efforts in explore benefits of betel fruit is to formulatedinto mouthwash. The aim of this research was to prepared stable and effective mouthwash preparation which is inhibit the growth of Streptococcus mutans. There were 3 formula designed by varying the concentration of the piper betle fruit juice 3, 4 and $5 \% \mathrm{v} / \mathrm{v}$ respectively. Stability evalution carried out before and after accelerated condition at $5^{\circ} \mathrm{C}$ and $35^{\circ} \mathrm{C}$ for 10 cycles in which the parameter were organoleptic, $\mathrm{pH}$ value, viscosity and inhibitory Streptococcus mutans of the bacteria. The assay results of the inhibition of each formula with agar diffusion method showed that the 3 formula were able to inhibit the growth of Streptococcus mutans, but the most optimum stability and effective inhibiting Streptococcus mutans was formula F3, that contain $5 \%$ fruit juice, due to there was no significant change before and after accelerated condition.
\end{abstract}

Key word : Mouthwash, Piper betle fruit (Piper betle L.), Streptococcus mutans

\section{PENDAHULUAN}

Sirih (Piper betle L.) merupakan tumbuhan yang telah lama dipakai dalam pengobatan tradisional oleh orang Indonesia dan bangsa-bangsa Asia lainnya. Pengobatan tradisional yang mereka lakukan hanya berdasarkan pengetahuan dan pengalaman nenek moyangnya atau secara empiris, belum berdasarkan penelitian secara medis-farmakologis.

Sirih buah secara empiris oleh masyarakat Maluku Utara khususnya di kota Tidore Kepulauan dipercaya dapat menjaga kesehatan gigi dan mulut, mereka meyakini dengan mengunyah bulir buah sirih dapat menjaga kualitas kesehatan gigi dan mulut mereka, namun sayangnya pemanfaatan dan khasiat dari bulir buah sirih belum teridentifikasi secara ilmiah.

Obat kumur merupakan larutan yang mengandung zat berkhasiat antibakteri untuk mengurangi jumlah mikroorganisme dalam mulut, digunakan sebagai pembilas rongga mulut, mudah digunakan, dan dapat 
mencapai area permukaan di dalam rongga mulut yang sulit dicapai oleh sikat gigi. Obat kumur dapat mengandung zat berkhasiat sintetis atau yang berasal dari bahan alam (Wardani, 2012). Dibagian barat Nusantara dari tumbuhan sirih (Piper betle L.) yang digunakan adalah daun, sedangkan dibagian timur Nusantara mulai dari wilayah laut timur Sulawesi yang digunakan adalah bulir buah dari varietas Siriboah, yang merupakan varietas dari sirih yang dapat menghasilkan buah. Sirih buah ini hanya di budidayakan di bagian timur Indonesia. Di Maluku sirih buah menggantikan sirih daun, jika di daerah tersebut menggunakan daun maka dipilih daun muda dari siriboa yang dapat menyebabkan kepala merasa berat, daun yang tua sama sekali tidak bisa digunakan (Heyne, 1987).

Penggunaan sari buah sirih
dalam formulasi obat kumur merupakan salah satu usaha dalam mengeksplorasi manfaat dari buah sirih yang dikenal secara empiris mampu menjaga kesehatan gigi dan mulut. Selain itu, penggunaan sari buah sirih dalam obat kumur diharapkan dapat mengantikan obat kumur komersial yang memiliki sejumlah efek samping yang merugikan.

Sebagai antibakteri, kandungan sari buah sirih dalam obat kumur diharapkan mampu membunuh atau menghambat pertumbuhan dari bakteri penyebab plak gigi, bakteri streptococcus mutans merupakan spesies yang mendominasi komposis bakteri dalam pembentukan plak gigi. (Buchanon and Gibbons, 1974).

Penelitian ini bertujuan untuk menghasilkan sediaan obat kumur yang stabil dan efektif dalam menghambat pertumbuhan bakteri Streptococcus mutans.

\section{METODE PENELITIAN}

\section{Bahan yang digunakan}

Air aromatik $100 \%$, air suling, buah sirih (Piper betle L.) 10,0 gram, medium glukosa natrium agar, nutrient agar, nutrient broth, propilenglikol $25 \%$ $\mathrm{v} / \mathrm{v}$, sakarin $0,02 \% \mathrm{~b} / \mathrm{v}, \quad$ dan Streptococcus mutans

\section{Pembuatan sari buah sirih.}

Disiapkan 10,0 gram buah sirih (Piper betle L.) segar, dimasukan kedalam juicer. Ditambahkan air suling secukupnya, buah sirih (Piper betle L.) di blender, sari buah sirih yang diperoleh di saring menggunakan kertas saring, dimasukan kedalam 
wadah dan dicukupkan dengan air suling hingga 100,0 mL, untuk mendapatkan larutan stok $10,0 \mathrm{gr} /$ $100,0 \mathrm{~mL}$.

\section{Uji pendahuluan aktivitas} antimikroba sari buah sirih terhadap bakteri Streptococcus mutans.

Sari buah sirih (Piper betle L.) dipipet sebanyak 1,0 $\mathrm{mL}$ dimasukan kedalam vial dan ditambahkan 9,0 mL medium GNA, dihomogenkan, sehingga diperoleh konsentrasi $10 \%$ $\mathrm{v} / \mathrm{v}$. Campuran tersebut dituang ke dalam cawan petri, dihomogenkan dan dibiarkan memadat, selanjutnya di ambil 1 ose bakteri Streptococcus mutans digoreskan pada medium yang merupakan campuran dari medium GNA dan sampel, kemudian cawan petri diinkubasi pada suhu $37^{\circ} \mathrm{C}$ selama 24 jam. Diamati aktivitas antimikrobanya yang ditandai dengan ada tidaknya pertumbuhan mikroba.

\section{Uji KHM sari buah sirih terhadap} bakteri Streptococcus mutans.

Jika hasil uji pendahuluan aktivitas antimikroba diperoleh bahwa 1,0 mL sari buah sirih (Piper betle L.) dapat menghambat pertumbuhan dari bakteri Streptococcus mutans maka dilanjutkan dengan uji KHM dengan menyiapkan volume sampel uji yaitu
$0,5,1,2$ dan $4 \% \mathrm{v} / \mathrm{v}$, yang diisi kedalam masing-masing tabung reaksi, dan dicukupkan dengan medium NB hingga $10 \mathrm{~mL}$. selanjutnya ke IV tabung reaksi di inkubasi pada suhu $37^{\circ} \mathrm{C}$ selama 24 jam. Diamati KHM nya yang ditandai dengan kekeruhan atau zona bening pada medium.

\section{Uji KBM sari buah sirih terhadap} bakteri Streptococcus mutans.

Hasil inkubasi pada uji KHM dengan konsentrasi $0,5,1,2$ dan $4 \%$ $\mathrm{v} / \mathrm{v}$ digoreskan pada medium GNA dalam cawan petri dan diinkubasi kembali pada suhu $37^{\circ} \mathrm{C}$ selama 24 jam. Nilai KBM ditunjukkan dengan tidak adanya pertumbuhan bakteri pada konsentrasi terendah sampel.

\section{Pembuatan sediaan mouthwas.}

Sari buah sirih (Piper betle L.) diambil sebanyak 3,0 $\mathrm{mL}$ dimasukkan ke dalam erlenmeyer (wadah 1), kemudian pada wadah 2 dimasukan sakarin sebanyak 0,02 \% dengan 5,0 $\mathrm{mL}$ air suling diaduk hingga melarut. Larutan pada wadah 1 dicampur kedalam larutan pada wadah 2 lalu diaduk, setelah tercampur masukan air aromatik pada hingga mencapai konsentrasi 100,0 mL. Untuk kontrol positifnya dibuat formula yang hanya 
mengandung zat aktif sebesar $5 \%$ yang dilarutkan dengan air suling hingga 100,0 mL, sedangkan untuk kontrol negatif dibuat dari semua bahan tambahan tanpa ada zat aktif. Untuk formula 2 dan 3 cara kerjanya seperti diatas hanya jumlah zat aktifnya berbeda yaitu $4,0 \mathrm{~mL}$ dan 5,0 $\mathrm{mL}$.

\section{Uji Aktivitas Antibakteri Sediaan} Obat Kumur.

Medium NA dimasukan kedalam cawan petri, dibuat dua lapisan medium NA, lapisan pertama based layer sebanyak 10,0 mL dan lapisan kedua seed layer sebanyak 5,0 $\mathrm{mL}$ untuk lapisan kedua ditambahkan suspensi mikroba uji sebanyak 1 ose. Disiapkan 15 buah paper disk, tiap tiga buah paper disk dicelupkan kedalam masing-masing formula obat kumur dari sari buah sirih (Piper betle L.), kontrol positif dan kontrol negatif. Semua paper disk dicelupkan selama kurang lebih 1 jam, selanjutnya masing-masing paper disk ditanamkan pada cawan petri yang berisi medium NA dan biakan Streptococcus mutans, kemudian dinkubasi selama $1 \times 24$ jam pada suhu $37^{\circ} \mathrm{C}$, lalu diukur zona hambatan pertumbuhan bakteri.

\section{Uji stabilitas Sediaan Mouthwash.}

\section{Evaluasi kestabilan dilakukan} dengan mengukur beberapa parameter sebelum dan sesudah kondisi dipaksakan. Obat kumur disimpan pada suhu $5^{\circ} \mathrm{C}$ dan $35^{\circ} \mathrm{C}$ masing-masing selama 12 jam selama 10 siklus. Parameter yang diukur sebagai berikut : pengamatan organoleptik, pengukuran viskositas, pengukuran $\mathrm{pH}$ dan uji efektifitas daya hambat sediaan obat kumur terhadap bakteri Streptococcus mutans.

\section{HASIL PENELITIAN}

Tabel 1. Hasil pengamatan organoleptik sediaan obat kumur sari buah sirih (Piper betle L.) sebelum dan sesudah kondisi penyimpanan dipercepat.

\begin{tabular}{cccc}
\hline \multirow{2}{*}{ Formula } & \multirow{2}{*}{ Jenis Pemeriksaan } & \multicolumn{2}{c}{ Kondisi di paksakan } \\
\cline { 3 - 4 } & Bau & Sebelum & Sesudah \\
\hline \multirow{2}{*}{ Formula 1 } & Rasa & Khas aromatis & Khas aromatis \\
& Warna & Mint & Mint \\
& Kejernihan & Kuning & Kuning \\
& Bau & Jernih & Jernih \\
\hline \multirow{2}{*}{ Formula 2 } & Rasa & Khas aromatis & Khas aromatis \\
& Warna & Mint & Mint \\
& Kejernihan & Kuning & Kuning \\
& & Jernih & Jernih \\
\hline
\end{tabular}




\begin{tabular}{cccc}
\hline & Bau & Khas aromatis & Khas aromatis \\
Formula 3 & Rasa & Mint & Mint \\
& Warna & Kuning & Kuning \\
& Kejernihan & Jernih & Jernih \\
\hline
\end{tabular}

Tabel 2. Hasil pengukuran viskositas rata-rata sediaan obat kumur sari buah sirih (Piper betle L.) dengan menggunakan Viskometer Brookfield sebelum dan sesudah penyimpanan

\begin{tabular}{ccccc}
\hline Kondisi dipaksakan & $\begin{array}{c}\text { Formula 1 } \\
\text { (Poise) }\end{array}$ & $\begin{array}{c}\text { Formula 2 } \\
\text { (Poise) }\end{array}$ & $\begin{array}{c}\text { Formula 3 } \\
\text { (Poise) }\end{array}$ & $\begin{array}{c}\text { Kondisi } \\
\text { dipaksakan }\end{array}$ \\
\hline Sebelum & 0,043 & 0,045 & 0,047 & Sebelum \\
Sesudah & 0,041 & 0,042 & 0,044 & Sesudah \\
\hline
\end{tabular}

Tabel 3. Hasil pengukuran $\mathrm{pH}$ rata-rata sediaan obat kumur sari buah sirih (Piper betle L.) dengan menggunakan $\mathrm{pH}$ meter sebelum dan sesudah penyimpanan dipercepat

\begin{tabular}{cccc}
\hline \multirow{2}{*}{ Kondisi } & \multicolumn{3}{c}{ Formula } \\
\cline { 2 - 4 } & F 1 & F 2 & F 3 \\
\hline Sebelum & 5,31 & 5,44 & 5,63 \\
Sesudah & 4,94 & 5,25 & 5,48 \\
\hline
\end{tabular}

Tabel 4. Hasil pengujian efektivitas sediaanmouthwash dapat dilihat dengan pengukuran daya hambat terhadap bakteri Streptococcus mutans.

\begin{tabular}{cccccc}
\hline \multirow{2}{*}{ Kondisi } & \multicolumn{2}{c}{ Kontrol $(\mathbf{m m})$} & \multicolumn{3}{c}{ Formula $(\mathbf{m m})$} \\
\cline { 2 - 6 } & Positif & Negatif & F1 & F2 & F3 \\
Sebelum & 12,33 & - & 8,33 & 9,67 & 11,67 \\
Sesudah & & - & 4,67 & 8,33 & 10,33 \\
\hline
\end{tabular}

\section{PEMBAHASAN}

\section{Uji Daya Hambat Sari Buah sirih.}

Hasil dari uji pendahuluan aktifitas antimikroba $1,0 \mathrm{~mL}$ sari buah sirih mampu menghambat pertumbuhan bakteri Streptococcus mutans,sehingga dapat dilanjutkan dalam Penentuan Konsentrasi Hambat Minimum (KHM) sari buah sirih (Piper betle $L$.), penentuan nilai KHM dengan pengataman terhadap tingkat kekeruhan pada konsentrasi 0,5, 1, 2 dan $4 \% v / v$ menunjukan nilai KHM yang belum dapat teramati karena semua tabung berwarna kecoklatan yang dipengaruhi oleh warna sari buah sirih (Piper betle L.) sehingga sulit untuk menentukan tingkat kekeruhan antar tabung. Untuk mengetahui efek antimikroba sari buah sirih (Piper betle L.) maka hasil inkubasi uji KHM dilanjutkan pada uji Kadar Bunuh Minimum (KBM). Hasil yang diperoleh pada uji KBM sari buah sirih (Piper 
betle L.) menunjukan pada konsentrasi $1 \%$ mampu menghambat pertumbuhan bakteri Streptococcus mutans ditandai dengan tidak adanya pertumbuhan bakteri pada media uji. Berdasarkan hasil uji KBM maka dalam formulasi obat kumur, konsentrasi sari buah sirih (Piper betle L.) yang digunakan ditingkatkan 3 sampai 5 kali KBM menjadi 3, 4 dan 5 $\% \mathrm{~V} / \mathrm{v}$. Adanya variasi konsentrasi tersebut bertujuan untuk membandingkan konsentrasi mana yang daya hambatnya lebih efektif terhadap bakteri Streptococcus mutans, sehingga menghasilkan formula F1, F2 dan F3.

\section{Uji Kestabilan Formula Obat Kumur.}

Pengujian kestabilan ketiga jenis formula dengan variasi konsentrasi zat aktif dilakukan dengan metode kondisi dipaksakan (stress condition) dengan penyimpanan pada suhu $5^{\circ} \mathrm{C}$ dan $35^{\circ} \mathrm{C}$ selama 10 siklus, masing-masing siklus berdurasi 12 jam. Tujuan dilakukannya kondisi dipaksakan adalah untuk mengetahui kestabilan formulasi dengan cara mempercepat proses peruraian formulasi dan untuk mempercepat waktu pengujian. Pengujian ini dilakukan dengan beberapa parameter, yaitu :

\section{Pengamatan Organoleptik}

Pemeriksaan organoleptik, dilakukan meliputi perubahan bau, rasa, warna dan kejernihan sebelum dan sesudah kondisi dipaksakan (dapat dilihat pada tabel 1).

\section{Pengukuran Viskositas}

Hasil pengukuran viskositas pada awal dan akhir pengamatan menunjukan adanya penurunan viskositas. Adanya variasi temperature pada kondisi dipaksakan yang akibatnya daya viskositasnya menjadi sedikit encer (table 2). Menurut Ansel (2005) viskositas sediaan akan berubah-ubah tergantung pada temperatur,umumnya viskositas cairan berkurang dengan meningkatnya temperatur. Berdasarkan dari hasil perhitungan statistik dengan metode Rancangan Acak Kelompok (RAK), terdapat penurunan viskositas yang sangat signifikan dari ketiga formula sebelum dan sesudah kondisi dipaksakan yang menunjukanbahwa ketiga formula tidak stabil.

\section{Pengukuran pH}

Pengukuran $\mathrm{pH}$ dilakukan sebelum dan sesudah kondisi penyimpanan dipercepat. Pengukurun nilai $\mathrm{pH}$ bertujuan untuk mengamati perubahan $\mathrm{pH}$ yang mungkin terjadi pada sediaan obat kumur selama masa penyimpanan. Perubahan nilai 
$\mathrm{pH}$ dari obat kumur akan dibandingkan dengan kisaran nilai $\mathrm{pH}$ yang sesuai untuk sediaan yang digunakan secara oral. Ini berkaitan dengan keamanan penggunaan sediaan untuk menghindari agar nilai $\mathrm{pH}$ sediaan tidak mengurangi atau menghilangkan efektifitas dari sediaan. Hasil penelitian diperoleh (table 3).

Menurut Martin (1971) pH 5,0 9,5 merupakan $\mathrm{pH}$ yang aman dengan $\mathrm{pH}$ optimum 6,5 - 7,0 untuk cairan penggunaan oral. Dari hasil pengamatan dapat disimpulkan bahwa selama masa penyimpanan F2 dengan nilai pH 5,44 turun menjadi 5,25 dan F3 dengan nilai $\mathrm{pH}$ 5,63 turun menjadi 5,48 , penurunan nilai $\mathrm{pH}$ ini masih sesuai dengan kisaran $\mathrm{pH}$ aman untuk cairan yang digunakan secara oral. Sedangkan untuk $\mathrm{F} 1$ dengan nilai $\mathrm{pH}$ 5,31 turun menjadi 4,94, penurunan nilai $\mathrm{pH}$ ini telah melebihi kisaran $\mathrm{pH}$ sediaan yang digunakan secara oral.

\section{Pengukuran zona hambatan}

Pengukuran zona hambatan dilakukan untuk mengetahui formula yang menunjukan efektifitas paling baik dalam menghambat pertumbuhan bakteri Streptococcus mutans, yang merupakan bakteri penyebab terjadinya plak gigi. hasil pengamatan (table 4) menunjukan F3 memiliki zona hambatan yang lebih besar dibandingkan dengan zona hambatan yang dimiliki F1 dan F2. Zona hambatan tiap formula obat kumur sebelum kondisi dipaksakan berturutturut $8,33 \mathrm{~mm}, 9,67 \mathrm{~mm}$ dan 11,67 $\mathrm{mm}$, dan setelah kondisi dipaksakan menurun menjadi $4,67 \mathrm{~mm}, 8,33 \mathrm{~mm}$ dan 10,33 mm. Hasil analisis statistik menunjukan bahwa F3 dan F2 tidak memperlihatkan perubahan zona hambatan yang sangat signifikan sebelum dan sesudah kondisi dipaksakan.

\section{KESIMPULAN}

Berdasarkan hasil penelitian dapat disimpulkan bahwa formula yang memiliki kestabilan optimum dan efektif dalam menghambat aktifitas bakteri Streptococcus mutans adalah formula F3, yaitu formula obat kumur dengan konsentrasi sari buah sirih (Piper betle L.) $5 \%$ karena tidak ada perubahan yang signifikan sebelum dan sesudah kondisi dipaksakan.

\section{DAFTAR PUSTAKA}

Al-Bayaty F.H, Al-Koubaisi A.H., Ali Wahid N.A. and Abdulla M.A.. 2010. Effect of mouth wash extracted from Salvadora persica (Miswak) on dental plaque formation: A clinical trail.J. Med. Plants. Res. 4 (14) 1446-1454 
Ansel,H.C., Terjemahan. 2005, Pengantar Bentuk Sediaan Farmasi, Edisi keempat, penerjemah Farida Ibrahim, Penerbit Universitas Indonesia, Jakarta.

Aryanti, Harsojo, Yefni. S, Tri M.E,. 2007. Isolasi Dan Uji Antibakteri Batang Sambung Nyawa (Gynura Procumbens Lour) Umur Panen 1, 4 Dan 7 Bulan. Jurnal Bahan Alam Indonesia Vol. 6 No.2. 45

Aulton M.E., 1988. Pharmaceutics; The Science of Dosage Form Design. Churchill Livingstone. New York.

Banker., G. S, and Rhodes. T. C. 1995. Modern Pharmaceutic Third Edition. Marcel Dekker Inc : New York

Buchanon, R.E, and Gibbons, N.E., 1974. Berhey's Manual Of Determinative Bacteriology. $8^{\text {th }}$ Edition. The Willam and Wilkins Company. United States Of America.

Carter, S.J,. Cooper. JW,. And Collin Gunn's. 1978 Dispensing for Pharmaceutical Student. Ed. XII, Pitman Publishing Ltd, London

Damayanti R. 2003. Khasiat \& Manfaat Daun Sirih Obat Mujarab dari Masa ke Masa. PT Agromedia Pustaka : Jakarta

Difco, 1988. Cultur Media Handbook, E. . Merck, Darmstadt, Federal Republic of Germany.

Direktorat Jendral Pengawasan obat dan Makanan., 1979. Farmakope Indonesia, Edisi
Ketiga, Departemen Kesehatan Republik Indonesia., Jakarta

Direktorat Jendral Pengawasan obat dan Makanan., 1995. Farmakope Indonesia, Edisi Keempat, Departemen Kesehatan Republik Indonesia., Jakarta.

Djide, M.N., and Sartini., 2008. Dasar dasar Mikrobiologi Farmasi. Lembaga Penerbit Universitas Hasanudin (Lephas): Makassar.

Garrity, G.M., Bell, J. A., and Lilburn, T.G., 2004, Taxonomic Outline of The Prokaryotes Bergey's Manual of Systematic Bacteriologi, $2^{\text {th }}$ Edition, Spiringer, New York Berlin Hendelbergh, United states of America.

Gennaro, A. R., 2000. Remington's Pharmaceutical Sciences $20^{\text {th }}$ Edition Mack Publishing Company, Baltimore, Maryland 21202, United States Of America.

Heyne. K,. Terjemahan. 1987. Tumbuhan Berguna Indonesia Jilid II. Badan Litbang Kehutanan : Jakarta

Keithler, W.M.R. 1956. The formulation of Cosmetics and Cosmetics Spacialties. Drug and Cosmetic Industry, New York,

Kibbe, A.H,. 2000. Handbook of Pharmaceutical Excipients sth $^{3 \text {, }}$ American Pharmaceutical Press, Washington DC.

Lisdawati, V. Daroham, M. Sukmayanti, A. Nugroho, YA. 2008. Karakterisasi Daun Miana (Plectranthus scutellarioides (L.) 
Bth.) Dan Buah Sirih (piper betle I.) Secara Fisiko Kimia Dari Ramuan Lokal Antimalaria Daerah Sulawesi Utara. Media Litbang Kesehatan Volume XVIII Nomor 4 . 217

Martin, A., Swarbick, J., Cammarata,. A. 1993. Farmasi Fisika. University of Indonesia Press. Jakarta.

Martin. 1971. Dispensing of Medication $7^{\text {th }}$ edition. Marck Publishing Company ; USA.

Nugroho,YA. 2009.

PembuatanFormula dan Uji Aktivitas Obat Anti Malaria Berbasis Buah Sirih Menggunakan Vacuum
Draying. Badan Litbangkes: Jakarta.

Pelczar, Jr.M.J., \& Chan, ESC. Terjemahan. 1988. DasarDasar Mikrobiologi. Terjemahan Ratna Siri Hadioetomo, Teja, Imas, SutarmiTjitrosomo dan SriLestariAngka. UI-Press :Jakarta.

Wardani,I.A.M.K., 2012. Perbandingan Efek Antibakteri Berkumur Seduhan Daun Sirih (Piper betle Linn) dan Seduhan Teh Hitam (Camellia sinensis L.Kuntze) Terhadap Jumlah Colony Forming Unit (CFU)/ml Streptococcus mutans Pada Saliva. UK Maranatha : Bandung 